\title{
The Islamic Concept of Education Reconsidered
}

\author{
Khosrow Bagheri and Zohreh Khosravi
}

\begin{abstract}
Some authors have analyzed the Islamic concept of education in parallel to the assumed contrast between Islam and the liberal tradition. Hence, given the latter's rationalist tendencies, an almost indoctrinatory essence is assumed for the Islamic concept of education. However, we argue that rationality is involved in all elements of the Islamic concept of education. There might be some differences between the Islamic and liberal conceptions of rationality, but these are not so sharp that the derivative Islamic concept of education can be equated with indoctrination. We suggest an Islamic concept of education that includes three basic elements: knowledge, choice, and action. Then, we show that, according to the Islamic texts, these elements have a background of wisdom.
\end{abstract}

\section{Introduction}

In a recent volume of Comparative Education, Halstead introduced "an Islamic concept of education." As he admits, this concept still needs to be analyzed and its components to be shown. In what follows, we critique the above-mentioned analysis and some of the related views on which it relies. After this, we present an alternative view.

In summary, Halstead assumes a contrast between Islam and the liberal tradition and, in parallel, given that tradition's rationalist tendencies, concludes an almost indoctrinatory essence for the Islamic concept of educa-

Khosrow Bagheri Noaparast has a B.A. in psychology, an M.A. in the philosophy of education, and a Ph.D. in the philosophy of education from New South Wales University, Australia (1995). He is a professor in the Faculty of Psychology and Education (Department of Philosophical and Social Foundations) at the University of Tehran, Iran. Zohreh Khosravi has a B.A. and an M.A. in psychology and a Ph.D. in psychology (1996) from New South Wales University, Australia. She is an associate professor in the Faculty of Education and Psychology (Department of Psychology) at the University of al-Zahra, Iran. 
tion: "Independence of thought and personal autonomy do not enter into the Muslim thinking about education, which is more concerned with the progressive initiation of pupils into the received truths of the faith."

However, we argue here that rationality is involved in all elements of the Islamic concept of education. There might be some differences between the Islamic view of rationality and that of the liberal tradition; however, one should not conclude, as far as rationality is concerned, that there is a sharp contrast between Islam and the liberal tradition. Before going into the details of the argument, we emphasize here the place of wisdom in Islam.

The Qur'an contains many derivatives and synonyms of 'aql (wisdom), as in 15:80-82. What is the meaning of using wisdom in the Qur'an? When a person is in control of his/her cognitive attempts so that he/she becomes immune to slips of thought, and, as a consequence, reaches the understanding of the thing concerned, it can be said that he/she has used wisdom. Three factors play the main role in avoiding these slips: evaluating the soundness of reasons, having knowledge, and controlling love and hate.

As far as the first factor is concerned, using wisdom occurs when the person evaluates the adequacy and soundness of the reasons held. This element refers to using logic in evaluating the soundness of claims. The Qur'an provides the following example: When addressing the Jews and the Christians who had claimed that Prophet Abraham was the father of their particular religions, God says: "O People of the Book. Why do you dispute about Abraham, when the Torah [The Old Testament] and the Injil [The New Testament] were not revealed until after him? Do you not, then, understand [use wisdom]?" (3:65). In other words, given the historical precedence of Abraham to the Christians and the Jews, it is not reasonable to attribute these religions to him.

In relation to the second factor of having knowledge, whoever has more knowledge is better able to use wisdom at the level of cognition. In other words, having comprehensive knowledge and information enables the person to have access to more material for comparison and combining and, hence, to reach a deeper cognition or a more subtle recognition. With regard to this point, the Qur'an states: "And (as for) these examples, We set them forth for people, and none understand them but the learned" (2:44). The word understand (derived from 'aql) here refers to wisdom, and it is stated that being learned is required for being wise. That is to say, knowledge is a prerequisite for wisdom.

In regard to the third factor, using wisdom requires that the deviating interventions of love and hate be prevented, for just as love might prevent us from recognizing weaknesses, hate might prevent us from seeing strengths. 
When the two feet of love and hate are fastened by the band of wisdom, the person can be immune from any deviation in cognition and recognition. Thus, the Qur'an invites people to be aware of emotional deviations in evaluating past traditions: "And when it is said to them, follow what Allah has revealed, they say: 'Nay! We follow what we found our fathers upon.' What! And though their fathers had no sense at all, nor did they follow the right way?" (2:170). In other words, familiarity with particular traditions cannot be a full justification for considering them to be reasonable or right. The force of habit and social dependence should be distinguished from the force of reasonableness and truth. Thus wisdom, with its three elements of logic, knowledge, and emotional control, has an important place in Islam's view.

It is also worth mentioning here that the Islamic word for wisdom ( $a q l$ ) is wider than "reason" and, as Nasr says, refers to intellectus. ${ }^{3}$ According to him, the perennial philosophy holds that intellectus is distinct from ratio. ${ }^{4}$ While the latter is restricted to pure reasoning, the former refers to a deep insight at a higher level of the whole universe. It might be said that the Islamic concept of wisdom is more extensive than the Latin ratio and the Greek dianoia and, in fact, refers to the higher perceptive faculty of mindheart, which is called intellectus in Latin and nous in Greek, as, for instance, Plato considered noesis to be the highest level of intuitive knowledge. ${ }^{5}$

Perhaps the root factor in accounting for the difference between Islamic education and the rationalistic trend in liberal education needs to be sought in the two above-mentioned meanings. In the liberal tradition, intellectus is held to be reason, whereas Islam considers it to be wisdom. Having paved the ground for discussion, we now reconsider the Islamic view of education.

\section{Islamic Education: A Critique}

In his essay, Halstead seeks to disclose the somewhat unknown dimensions of the Islamic concept of education. As mentioned above, he asserts a contrast between the liberal and Islamic conceptions of education and tries to explain the latter. According to him, this contrast derives from a profound difference between Islam and western culture. Referring to al-Attas' view, he affirms that: "There exist such profound and absolute differences between Islam and western culture that they cannot be reconciled."

According to Halstead, liberalism regards rationality and intellectual freedom as its main pillar. Thus, he believes that the real Islamic view gives no legitimacy to autonomy and freedom of reason and, for that matter, to such rationalistic Muslims as the Mu'tazilites. Criticizing O'Hear's affirmation of the Mu'tazilites, he says: 
O'Hear (1982), for example, wrote approvingly of the Mu'tazilite belief that reason should be used "to assess the claims of revelation" and suggested (perhaps somewhat fancifully) that the Mu'tazilites would "presumably not be opposed to the intellectual freedom striven for in a liberal education" (p. 13). ${ }^{?}$

Halstead appeals to the views of such thinkers as al-Ghazali (1058-1111) to show the acceptable relation between religion and reason: "With the advent of al-Ghazali, however, the philosophical and rationalistic schools of thought lost ground. Al-Ghazali reasserted the dominance of religion over reason and gave superior status to revelation as a source of knowledge." ${ }^{\prime 8}$ Accepting such a relation between religion and reason, Halstead tries to analyze the Islamic view on education that, in the final analysis, leads to a religion-centered education, in contrast to the liberal education that he regards as rationalistic.

Taking such a foundation for his analysis, Halstead then tries to give an account of the Islamic view of education. He appeals to three Arabic words, tarbiyah (to cause to grow), ta'dib (to refine, to discipline), and ta lim (to instruct) that, according to him, refer to three basic dimensions of education: individual development, social and moral education, and acquisition of knowledge, respectively. In this analysis, he relies partly on al-Attas' suggestion, ${ }^{9}$ particularly in the case of $t a^{\prime} d i b$.

Let's begin with al-Attas, whose contribution to explaining the Islamic concept of education has been considered important..$^{10}$ Al-Attas denies that the Islamic concept of tarbiyah and the related word rubübiyah (God's being the Lord) can be considered as candidates for showing the dimensions of the Islamic concept of education. ${ }^{11}$ He claims that the root of these words (raba: to grow) indicates physical upbringing without any reference to the basic elements of real education, such as knowledge, intelligence, and virtue. According to him, God's rubübiyah does not include knowledge; rather, it refers to the same meaning of physical upbringing.

However, he could not maintain this awkward result to the end of his book. Hence, he admits that a knowledge-related meaning could penetrate the concept $r a b b$ (the Lord), but claims that such a meaning would refer merely to the possession of knowledge rather than to the transference of knowledge, which is essential in education. He cites as evidence the word rabbani, which is used in the Qur'an to refer to Jewish scholars. According to him, this word refers to a scholar who possesses knowledge, and he adopts the view that it might be a Hebrew word, rather than an Arabic word derived from $r a b b$. 
Al-Attas suggests that the Islamic concept of ta'dib could refer to education because, unlike rubübiyah, it refers to knowledge. In addition, the Prophet used it to refer to his being educated by God, as when he says: "My Lord disciplined me and disciplined me well." ${ }^{2}$ However, al-Attas' argument is unconvincing for several reasons. First, his insistence on delimiting the meaning of $r a b b$ to physical upbringing and negating its inclusion of knowledge is untenable and inconsistent with its usage in the Qur'an, where it is used in relation to knowledge. This indicates that knowledge refers to a component of its meaning: "Our Lord. You embrace all things in mercy and knowledge" (40:7).

Al-Attas would respond that in this case, the relation of rabb to knowledge merely indicates that God possesses it. However, delimiting the meaning to possession is not convincing, for management, which includes both physical and mental aspects, is also one dimension of this word's meaning. This point is quite clear in the very tradition on which al-Attas has placed his burden of argument. When the Prophet attributes $t a^{\prime} d i b$ to the $r a b b$, this clearly indicates that the former is a deed of the latter. If, as al-Attas claims, ta'dib indicates knowledge, then it follows that the meaning of $r a b b$ includes providing knowledge. This point has been made more than once in the Hadith literature. A further example is the Prophet's request from the $r a b b$ to increase his knowledge: "O Lord. Increase my knowledge" $(20: 114)$. If providing or increasing knowledge has no relevance to the $r a b b$, then using the word here would be misplaced. It is clear that, in the Islamic texts, the names of God are used properly in relation to the request concerned. When, for instance, a person requests for God's forgiveness, he or she mentions the relevant name al-Ghaffar (The Forgiver).

As for al-Attas' point that rabbani merely refers to the scholar's possession of knowledge, there are textual counter-examples. In the following Qur'anic verse, not only is rabbani used in relation to teaching, rather than the possession of knowledge, but it is also used in relation to rubübiyah: "Be worshippers (rabbanis) of the Lord because of your teaching the Book and your reading (it yourselves)" (3:79). In this verse, it is argued that because the clergy are teaching the holy book and reading it as well, they should have and show a strong relationship to God in their characteristics. This strong relationship to God, rather than the possession of knowledge, is what is meant by calling them rabbani. Therefore, this word relates to rubübiyah (God's being the Lord).

There are also some points in relation to al-Attas' suggestion that ta'dib is an adequate candidate for showing the dimensions of education. First, it is worth mentioning that $t a^{\prime} d i b$ and even the derivatives of its root $a d u b a$ do 
not appear in the Qur'an at all. Second, contrary to what al-Attas says, it is not true that $a d a b$ and $t a{ }^{\prime} d i b$ are more comprehensive than rabb in referring to both knowledge and action. Adab does not necessarily indicate knowledge involvement. That is why it can refer to punishment as well as to animal training and hence, contrary to what al-Attas says, it is not specific to humans. Thus, the Hadith literature mentions that "all debauchery is wrong, except in disciplining horses." "13 Finally, contrary to al-Attas, not only is ta'dib inferior to rubübiyah in showing the dimensions of education; it is, in fact, a subsumption for rubübiyah because $t a^{\prime} d i b$, at best, refers to ethical and social aspects of education, without including instruction in the sciences and the like. This point will be explained further in the next section. ${ }^{14}$

Now we turn to Halstead's suggestion. First, we need to recognize the methodological aspects of his view. Relying on Islamic religious texts as resources for exploring the basic elements of the Islamic concept of education, Halstead takes an objective standpoint insofar as the methodology of understanding these texts is concerned: "The goals of education are laid down by revealed religion and therefore have an objective quality; they do not vary according to individual opinion or experience." 15

However, as recent debates in hermeneutics have shown, ${ }^{16}$ texts need to be interpreted and penetrating interpretations cause different views to appear. Even if we avoid radical standpoints in hermeneutics that claim, following Friedrich Nietzsche, that "everything is interpretation," this is still a far cry from the objective view of claiming that meaning is over there in the text. In actual fact, the discrepancy among Muslim scholars throughout the history of Islam shows that such an objective quality is not defensible. What Halstead himself refers to in the history of Islam shows this well: While Mu'tazilite (rationalist Muslims) believed that Islamic teachings should be based on reason, orthodox Ash arite theologians held that whatever is revealed from God is reasonable.

This kind of discrepancy appears in the realm of Islamic education as well. For instance, while Halstead relies on al-Attas' suggestion of ta'dib, unlike him and rightly, I suppose, he delimits this suggestion to one dimension of education, namely, its social and moral aspect. And what is at stake in the present essay is a further sign of the discrepancy in understanding and interpreting Islamic texts.

The second point in Halstead's interpretation of the Islamic concept of education is that he, as a result of his commitment to the priority of revealed knowledge over reason, as advocated by such thinkers as al-Ghazali, equates it with indoctrination or, at least, regards it as including indoctrination. This agrees with what advocates of liberal education claim about religious edu- 
cation (including Islamic education) in general. For instance, Hirst claims that not only is the phrase religious education meaningless, but also that it indicates indoctrination whenever it refers to the realm of practice. ${ }^{17}$

In trying to show a sharp contrast between the liberal and Islamic conceptions of education, Halstead also claims that the latter, unlike the former, does not embrace a critical view on what is revealed: "Independence of thought and personal autonomy do not enter into the Muslim thinking about education, which is more concerned with the progressive initiation of pupils into the received truths of the faith." 18 This indicates that education is not a rational matter in which pupils are required to think and judge on what is taught; rather, they just need to follow what is revealed from God. In other words, education is the same as indoctrination.

This conception of education is based, in turn, on a view of the nature of religion in general and of Islam in particular. This view, which I call encyclopedic, holds that Islam includes all kinds of true knowledge and information that people need:

... the divine revelation expressed in the shari'a provides them with the requisite knowledge of truth and falsehood, right and wrong, and the task of [the] individual is to come to understand this knowledge and exercise their free will to choose which path to follow. ${ }^{19}$

Both of these points, namely, the entire meaning of Islamic education and its underlying philosophy of religion, could be challenged. Concerning the nature of Islamic education, it is doubtful whether it can really be equated with indoctrination. I have criticized this view elsewhere with reference to Hirst's above-mentioned claim in this regard. ${ }^{20}$ In addition, it is worth mentioning here that when the Prophet introduced Islamic teachings, he prevented people from blindly accepting their cultural heritage: "Nay! They say: We found our fathers on a course, and surely we are guided by their footsteps... (The Warner) said: What! Even if I bring to you a better guide than that on which you found your fathers?" (43:22-24).

This is an invitation to think about received beliefs and, as a result, opposes indoctrination. One should not say that indoctrination, in the case of Islam's "correct" beliefs, is defensible, far there is no "good" and "bad" indoctrination. Rather, indoctrination is altogether "bad" unless it is inevitable, like what occurs during early childhood when there is no foundation for rational thinking. In addition, when one talks about Islam's "correct" beliefs, this "correctness" needs to be understood by the person who is addressed. This shows that admitting indoctrination in the case of "correct" beliefs is self-contradictory. 
As for Halstead's presumed philosophy of religion, there is not enough space here to deal with it properly. Suffice it to say that there is neither intratextual nor extra-textual evidence to support the encyclopedic view of Islam. So far as the intra-textual evidence is concerned, the Islamic texts do not claim that they are responsible for giving all of the knowledge and information that human beings need. In fact, religion does not eliminate reason. Neither is there any extra-textual or rational argument to support the encyclopedic view. Actually, there could not be such an argument because according to this view, reason goes on holiday.

Finally, the third point in Halstead's analysis is his triadic structure of tarbiyah (to cause to grow), ta'dib (to refine, to discipline), and ta 'im (to instruct). According to him, the first word refers to individual development, the second to social and moral education, and the third to acquiring knowledge. There are several challenges to this point. The first one is that the Qur'an uses tarbiyah merely to refer to physical upbringing, as al-Attas has also shown, ${ }^{21}$ rather than to the extended meaning of individual development. In analyzing this word, Halstead talks about it as an Arabic word. It is worth mentioning that the meaning of words in Arabic is not the determining factor here; rather, what is important is to see how they are used in the Qur'an and other Islamic texts. The usage of tarbiyah in the Qur'an shows that it refers to physical upbringing, as is seen in Pharaoh's address to Moses: "Did we not bring you up as a child among us?" (42:18). It is clear that Pharaoh was not concerned about Moses' individual development.

The second challenge is the pupils' supposed passivity in both ta'dib (social and moral education) and ta lim (the acquisition of knowledge). Concerning the former, Halstead's support of indoctrination was criticized previously. As for the latter, he says:

Certainty may sometimes be achieved through an acceptance of the authority of the teaching of the 'ulama' (the learned) about the Qur'an and the Prophet. Islam, therefore, encourages an attitude of respectful humility towards such legitimate authority and trust in the truth of the knowledge that it hands down." 22

How could this conclusion be acceptable in Islam, given that Qur'an 9:31 criticizes the previous prophets' followers for their unreasonable humility toward their ulama (the learned)? This indicates that the followers should be critical of the learned and always be aware of the correspondence of their views to certain criteria. In other words, authority in and of itself has no legitimacy. 
Again, referring to Ibn Khaldun, ${ }^{23}$ Halstead says:

Muslims have long recognized that students' education is as likely to occur 'through imitation of a teacher ... the teacher, as transmitter of (religious) knowledge, is considered an authority figure worthy of respect (and therefore not generally open to challenge by students). ${ }^{24}$

It is clear that there is considerable room for role modeling in Islam. However, what needs to be addressed in this regard is whether or not it can take the shape of blind imitation. It seems defensible to hold that, according to the Qur'an, taking role models should not done blindly; rather, it must be active and in accordance with specific criteria. If Halstead acknowledges that the Qur'an does not support the blind acceptance of tradition, ${ }^{25}$ why does he regard the teacher as "an authority figure worthy of respect (and therefore not generally open to challenge by students)"?

Accepting those role models that meet specific criteria characterizes the Islamic view of authority. This can be seen in an order given to the Prophet to follow the previous prophets: "These are they whom Allah guided; therefore, follow their guidance" (6:90). What is required here is not an unqualified following ("follow them"); rather, it is a qualified following limited by guidance ("follow their guidance"). Even though they were prophets, the subsequent prophet should only follow their guidance. In other words, following should be criterion-based and, hence, active and selective.

On the whole, it is not acceptable to make a sharp contrast between Islam and the liberal tradition in terms of rationality. The autonomy that liberal thinking attributes to knowledge is to be understood as indicating that the legitimacy of knowledge claims is due to experience and relevant evidence, rather than to relying on religious beliefs. ${ }^{26}$ Challenging this view will paralyze human knowledge, and Islam does not call for replacing reason by religion. Halstead says that "the autonomy of the subject or discipline, at least as understood in liberal thinking, is excluded, for all subjects and all knowledge need the guiding spirit of religion to give them purpose and direction. ${ }^{27}$ If by giving purpose and direction he means that different branches of knowledge need to take the legitimacy of their findings from religion, this amounts to paralyzing human knowledge. And if he refers only to the realm of applying knowledge findings, it must be said that the liberal claim of autonomy of knowledge findings is predominantly related to the realm of explanation rather than of application.

As Halstead's proclaimed sharp contrast between Islam and liberal thinking is not defensible, his parallel conclusion as regards education is also problematic. He concludes that Islamic education, in contrast to liberal edu- 
cation, is mostly faith-oriented, authoritarian, and inclusive of indoctrination. Given the meaning of 'aql (wisdom) in the Qur'an, as explained above, Islamic education should embrace logical reasoning, doubt inherited beliefs and even the elements of faith, challenge tradition, and engage in critical thinking. The question as to which concept of education can be attributed to Islam is the subject of the following section.

\section{The Islamic Concept of Education: An Alternative}

We suggest that the basic components of the Islamic concept of education be sought in the word rubübiyah, which is used abundantly in the Qur'an and refers to God as the Lord. As explained in the first section, al-Attas was right in saying that tarbiyah refers merely to physical upbringing. However, he is wrong in giving the same meaning to rubübiyah, for the latter is not only used frequently in the Qur'an, but also has assumed a central position in the prophets' endeavors to provide knowledge to and develop their people. That is to say, the prophets invited their people to take God as their Lord, a practice that shows the real essence of Islamic education in particular and of religious education in general. We will explain this point below.

First, it should be explained why the invitation to take God as one's Lord is regarded as central. Given that the human beings' main problem lies in choosing among different "lords," it is inevitable that they will eventually choose a lord. They might take their own desires as their Lord, those of other peoples, or both. Whatever is taken as the source of regulation for their deeds is considered their Lord. When something is taken as the Lord, it begins to shape their characteristics according to its own. Thus, there is a clear relationship between choosing a lord and a certain kind of actualization of people's possible states. And this is exactly the point that relates to having a lord to education.

Accordingly, Islamic education could be defined as "to know God as the unique Lord of the human and the world, to select Him as one's own Lord, to undertake His guidance and regulations, and to avoid what is contrary to them." According to this definition, education refers to the process of becoming divine. Three basic elements are involved in this process: knowledge (of God as the Lord), choice (choosing God as one's Lord), and action (undertaking God's Lordship throughout one's life). These three elements involve rationality.

First, knowing God as He has introduced Himself in the Qur'an involves rationality. In other words, in order to know God as, to say the least, the unique Lord of the world or that there will be a day (the Day of Judg- 
ment) on which God will be the Lord and will evaluate all human beings' actions throughout their lives, one needs to understand the reasons God has given for each of the cases in the Qur'an and, thereby, to be persuaded internally without external coercion or indoctrination. As mentioned above, the Qur'an states that a rational faith (including faith in God) cannot be based on the blind imitation of outstanding personalities or on the blind acceptance of given traditions. Hence, deriving knowledge about God from the Qur'an naturally involves rationality and requires that one read it and think about what is stated therein in a rational manner.

Given that knowledge is involved as an element in Islamic education, the pupils could - and should - pose doubts about faith claims and examine their reasonableness. Thus, there can be no authoritative faith that needs to be imparted through indoctrination. It is worth mentioning here that the Qur'an itself shows that the basic beliefs can be challenged even before God, and that the answer should be reasonable rather than authoritative:

And when Abraham asked: "My Lord. Show me how You give life to the dead." He said: "What! Do you not believe?" He said: "Yes, but that my heart may be at ease." He said: "Take four of the birds, cut them into small pieces, place a part of them on every mountain, and then call them. They will come to you flying. Know that Allah is Mighty, Wise." (2:260)

It should be added that even though there should not be authoritative knowledge and that faith should be acquired on the basis of reasonability, rationality is used here in its wide sense. According to this meaning, one cannot only be positively rational about what is within the realm of the reason, but can also be negatively rational and silent about what is outside of reason's explicit boundaries. In other words, accepting these limits is in itself a rational matter.

The second element, namely choosing God as one's Lord, also involves rationality. Given that one has acquired rational knowledge about God to the effect that $\mathrm{He}$ is the Lord, it is naturally quite rational to choose Him as one's Lord. David Hume's well-known assertion that there is a logical gap between "is" and "ought" might be recalled here. ${ }^{28}$ According to him, one cannot logically deduce an "ought" from premises that contain an "is." It is not necessary to deal with this argument in detail here..$^{29}$ Given that this claim is valid, we are concerned here only about what is rational. In other words, there is a recognizable difference between something being logically valid and rationally valid. Again, rationality here is referred to in a wide sense of the word. Every logically valid point is also rationally valid, but not necessarily vice versa. While it might not be logically valid to follow an "ought" in the pres- 
ence of an "is," it is usually considered rational or reasonable to do so according to common sense. In their daily lives, people consider it rational to change their "decisions" after becoming aware of some new "facts."

This commonsense affair can also be expressed in a logical manner, namely, according to the practical syllogism as it was formulated by Aristotle. ${ }^{30}$ In a practical syllogism, a premise containing an "is" is combined with a premise containing an "ought" followed by a conclusion containing an "ought." The premise containing an "ought" in such a syllogism is usually an inner and personal obligation like "I should experience happiness in my life," and the premise containing an "is" declares a means-end claim that shows the dependence of happiness on some beliefs or actions. Hence, given the inner obligation on the one hand, and the reasoned statement indicating that God is the Lord of the world (and that happiness depends on being in congruence with the Lord) on the other hand, one can rationally - and even logically - conclude that he or she should choose and obey the Lord.

Given that the second element of Islamic education, namely, choosing God as one's Lord, is rational, it follows that faith in God should also be rational. Mere habit, cultural heritage, or indoctrination cannot be the basis for real faith in God. Even though these things are inevitable in childhood, as soon as one is able to think rationally, his or her inherited faith should be shaken by doubts and supported by good reasons; otherwise, it cannot be considered as "faith" proper.

Finally, the third element of Islamic education, namely, undertaking God's sayings and acting according to them, should also be rational. Thus, there should be reasons for doing the acts. That is why, in almost all cases of demanding action, the Qur'an states some reasons. For instance, in the case of fasting we read: "O you who believe. Fasting is prescribed for you, as it was prescribed for those before you, so that you may guard (against evil)" (2:183). In giving this prescription, God does not take an authoritative position; rather, the reason is mentioned immediately after giving the prescription: managing one's inner inclinations so that one may guard against evil.

According to this third element, rational action is a component of education. The two parts of "rational action" need to be taken into consideration. As for being "rational," the actions required of a pupil should be shown to be reasonable. That is to say, blind actions have no educative value. Concerning the second part, namely, "action," it should be emphasized that education involves action. In other words, education is not merely a cognitive or emotive matter; rather, the person should perform some deeds in order to develop his or her capabilities. Referring to the important place of action in Islam, Rom Harré says: 
Muslim moral psychology is the only traditional morality I know of with a well-articulated psychological theory of moral development. It is a conative, not a cognitive, theory ... Hence, all the will-strengthening techniques like the Ramadan fasts and the various other forms of self-denial. They are not to mortify the flesh, a kind of moral sadomasochism; they are to strengthen the will because that is the path of moral development. ${ }^{31}$

Harré is quite right in claiming a special place for action in Islamic morality. However, as explained above, one should not conclude, as Harré's statement might indicate, that this morality is not cognitive at all. "Rational action," being emphasized in Islam, indicates that there should be a cognitive aspect for action. To follow the well-known Kantian phrase, we could say that Islam holds the following ideas to be true: "Action without reason is blind, and reason without action is empty."

Given that Islamic education holds that action should be reasonable, it follows that the relationship between pupils and teachers should not be based on the mere imitation of a teacher's deeds. Without any doubt, following an exemplar is a necessary part of education. But what is at issue here is that this following should be accompanied by insight. Teachers should explain why their actions should be followed. In this way, their authority is not due to their being teachers per se; rather, it is for the reasons and criteria that accompany their deeds.

So far, we have explained on conceptual and theoretical grounds that, according to Islam's basic concepts, education should follow a rational track. However, one might object that so far as the practical realm of Islamic countries is concerned, education takes the form of indoctrination. Then, the question will be: What can really be said about Islamic education in terms of rationality or indoctrination? It is undeniable that the educational centers in the Muslim world are largely indoctrinating their students. However, this by no means negates the necessity of reviving Islam's ideal concepts in the area education; rather, it shows the double necessity for such a revival. In fact, this kind of conceptual clarification is itself part of a critical endeavor with the existing situation and thus a necessary step toward long-term development.

It is interesting to note that this kind of irony is also more or less the case in western education today. In theory, the liberal tradition tries to distinguish between education and indoctrination and to avoid the latter in the educational centers. However, what is actually going in the West's educational centers is akin to indoctrination. It must be noted that it is not too difficult to create a "doctrine" from science and then indoctrinate the people with it. 
Referring to this point, the eminent historian and philosopher of science Paul Feyerabend states that the science of seventeenth- and eighteenthcentury Europe was indeed a tool for liberty and enlightenment; however, it cannot be deduced that science will always remain such a tool. He holds that neither in science nor in any other ideology can a natural element that would make it inherently liberating be found. Ideologies can be obliterated and turned into religions. He maintains that his critique of modern science is that it prohibits freedom of thought. ${ }^{32}$ Not only can science be transformed into a doctrine, but religion can agitate the process of scientific indoctrination. Taking this aspect into consideration, Feyerabend admires Californian Christian fundamentalists who have been able to eliminate the rigid formulation of Darwin's theory of evolution from school books and replace it with the Bible's account found in the Book of Genesis. ${ }^{33}$

On the whole, contrary to what is actually going on in the educational centers of both Islamic as well as western countries, it is necessary to revive and clarify basic concepts of education in order to pave the ground for bringing rationality into the educational centers. In this way, the Islamic views explained above are not restricted to the Muslim world; rather, since education needs to become more rational in general, we call upon all educationists and thinkers in the realm of education to adopt a rational approach to educational matters.

\section{Conclusion}

Even though there are important differences between the Islamic and the liberal traditions of thought, it is not acceptable to conclude that if rationality is the basic element of education in the liberal tradition, then the real essence of the Islamic concept of education should be sought in indoctrination instead of rationality. Nevertheless, the question as to rationality's essence and boundaries can be considered an open matter for discussion. As far as the Islamic view is concerned, human reason is not considered an omniscient entity (as some of the advocates of liberalism might claim) and, consequently, acknowledging the limits of human reason is itself regarded as a rational matter. Despite this, however, as this essay has shown, the basic elements of the Islamic concept of education have a background of rationality. By appealing to the Islamic concept of rubübiyah, an Islamic concept of education can be suggested that includes the three basic elements of knowledge, choice, and action. According to the Islamic texts, each of these three elements of education have a background of rationality or wisdom. 


\section{Endnotes}

1. J. M. Halstead, "An Islamic Concept of Education," Comparative Education 40, no. 4 (2004): 517-29.

2. Ibid., 519. Emphasis added.

3. S. H. Nasr, Knowledge and the Sacred (New York: 1989).

4. F. Schuon, Stations of Wisdom, tr. G.E.H. Palmer (London: 1978).

5. We owe this notification about the difference between reason and intellect to the editorial comments.

6. Halstead, Islamic Concept of Education, 526.

7. Ibid., 518.

8. Ibid.

9. S. M. N. al-Attas, "Preliminary Thoughts on the Nature of Knowledge and the Definition and Aims of Education, in Aims and Objectives of Islamic Education, ed. S. M. N. al-Attas (London, Hodder \& Stoughton: 1979), 19-47.

10. Ibid., 521.

11. S. M. N. al-Attas, The Concept of Education in Islam: A Framework for an Islamic Philosophy of Education (Kuala Lumpur: Muslim Youth Movement of Malaysia, 1980).

12. Ibid.

13. M. B. Majlessi, Bihar al-Anwar (Beirut: Dar Ihya' al-Turath al-Arabi, 1983), 64: 216 . Anywhere $t a$ 'dib and ta' 'im are used as synonyms, the usual meaning for the latter is the instruction of morality, rather than instruction in general. For instance, Imam Ali says that whoever takes himself as a leader for people should start with instructing ( $\mathrm{ta}$ ` lim) himself before going to instruct others. In this saying, ta'dib and ta' 'lim are used as synonyms, and it is clear that instruction refers to moral instruction. See his "Kalam,"in Nahj alBalaghah, 70.

14. The root $r a-b a-b a$ is more essential than $r a-b a-w a$. The latter, as well as $r a-$ $b a-a$ and $r a-a-b a$, are derived from $r a-b a-b a$. It is possible that because of overlaps among these words, the meaning of growth is mistakenly considered for ra-ba-ba. See H. Mostafavi, "Ra-ba-ba," in Al-Tahqiq fi Kalemate al-Quran al-Karim (Tehran: Bungahe Tarjemeh va Nashre Ketabunder, 1359).

15. Halstead, "Islamic Concept of Education," 519.

16. R. E. Palmer, Hermeneutics: Interpretation Theory in Schleirmacher, Dilthey, Heidegger and Gadamer (Evanston. IL: Northwestern University Press: 1969).

17. P. H. Hirst, Moral Education in a Secular Society (University of London Press: 1974).

18. Halstead, "Islamic Concept of Education," 519. Emphasis added.

19. Ibid., 524 .

20. N. K. Bagheri, Islamic Education (Tehran: Alhoda Publishers, 2001).

21. Al-Attas, Concept of Education in Islam. 
22. Halstead, "Islamic Concept of Education," 525. Of course, people should respect the ulama, but, as argued here, the legitimacy of their authority is criterion-based and, therefore, trust in them could not and - should not - be blind.

23. Ibn Khaldun, The Muqaddimah, vol. 3. tr. F. Rosenthal (Princeton, NJ: Princeton University Press, 1967). Original work published $1381 \mathrm{AH}$.

24. Halstead, "Islamic Concept of Education," 525.

25. Ibid., 250. As for the relation between a mujtahid (a legist who formulates independent decisions in legal or theological matters) and a muqallid (one who blindly follows a mujtahid), it is like the relation between a novice and a specialist. A novice, undoubtedly, should follow a specialist, given that the specialist is capable with regard to the criteria concerned. Acknowledging the necessity of criteria opens the door for an insightful following and, therefore, the possibility of challenging in principle. Qur'an 9:31 criticizes the followers of previous religions for taking their ulama as $r a b b$. This does not indicate, of course, that they had taken them as God, but that they followed their ulama's bid'ah (unjustifiable innovation) blindly. So, the followers should be allowed to ask ulama for the criteria of their fatwas, and the ulama should not be regarded as being beyond question and challenge.

26. See, for example, Hirst, Moral Education.

27. Halstead, "Islamic Concept of Education," 525.

28. David Hume, A Treatise of Human Nature (Oxford: 1951).

29. The distinction between fact and value was revived by Moor in the twentieth century. See G. E. Moor, Principia Ethica (Cambridge: Cambridge University Press, 1903 [1956]). He claimed that value cannot be considered as an objective reality and referred to it as a "naturalistic fallacy." In his later works, Moor gave a more considerable role to facts in values, but viewed it as a non-natural characteristic that supervenes on facts. See G. E. Moor, Philosophical Studies (New York: Humanities Press, 1922 [1951]). In other words, value is regarded as an epiphenomenon. See Nicholas Capaldi, The Enlightment Project in the Analytic Conversation (Boston: Kluwer Academic Publishers, 1998), 320.

30. Aristotle, Nicomachean Ethics, tr. T. Irwin (Indianapolis: Hackett, 1985) $3: 1144, \mathrm{~b}, 14-22$.

31. R. Harré, Personal Being (London: Basil Blackwell, 1983), 244.

32. P. Feyerabend, (1981). "How To Defend Society against Science," in Scientific Revolutions, ed. I. Hacking (Oxford University Press: 1981), 119-21.

33. Ibid., 129. 